\title{
Pharmacology of GABA-mediated inhibition of spinal cord neurons in vivo and in primary dissociated cell culture
}

\author{
Robert L. Macdonald and Anne B. Young \\ Dept. of Neurology, University of Michigan, Ann Arbor, Michigan 48109, U.S.A.
}

\begin{abstract}
Summary
Organization of the postsynaptic GABA-receptor chloride channel complex on spinal cord neurons
\end{abstract}

In this paper it is shown that the postsynaptic GABA-receptor chloride ion channel complex is composed of several functional subunits. There are probably at least two stereospecific locations on the receptor for GABA-binding and both must be occupied to obtain an increase in chloride conductance. The interaction between these sites is uncertain but there could be either positive cooperativity between the sites or only a requirement that both sites are occupied without occupation of either site affecting the affinity for GABA of the other site. There is a chloride conductance channel coupled to the GABA receptor which opens for an average of $20 \mathrm{msec}$ and has an average conductance of $18 \mathrm{pS}$. The GABA-coupled chloride channel may or may not have the same composition as the glycine coupled chloride channel.

In addition to the GABA-recognition site and the chloride ion channel, GABA-receptors must have additional binding sites or modulator sites where drugs can bind to modify GABA activation of the GABA-receptor. The convulsant PICRO binds to a site which is independent of the GABA-recognition site and PICRO reduces GABA responses. Barbiturates and benzodiazepines augment GABA-responses without reducing GABA-binding and thus they must bind to a modulator site independent of the GABA recognition site. Whether or not this is the same site as the PICRO binding site is uncertain. Thus, the GABA-receptorchloride ion channel complex is composed of at least: 1) two GABA-binding sites; 2) a chloride ion channel; 3) a convulsant binding site (PICRO-binding site) and 4) an anticonvulsant binding site. This organization serves several obvious purposes. First, since two GABA-molecules are required to activate GABA-coupled chloride ion channels, the dose-response relationship for GABA is sigmoidal and steep. Thus minor shifts in GABA affinity will produce large alterations in GABA-responses and the GABA receptor can be easily modulated. Second, since the receptor has binding sites for convulsant and anticonvulsant compounds which decrease and increase GABA-responses, GABAergic inhibition can easily be modulated.

\section{Introduction}

The neutral amino acid $\gamma$-aminobutyric acid (GABA) was initially identified in brain in 1950 $(1,2,3)$. Four years later Hayashi (4) suggested that GABA might play a role in the regulation of neuronal excitability and Florey (5) discovered that an extract of mammalian brain had an inhibitory action on crayfish stretch receptor neurons. When the active component of the brain extract was identified as GABA, Florey and his colleagues (6) suggested that GABA might be an inhibitory neurotransmitter in the mammalian central nervous system (CNS). The inhibitory action of GABA on mammalian CNS neurons was demonstrated by Curtis and coworkers (7) in 1959 using iontophoresis

Molecular and Cellular Biochemistry 38, 147-162 (1981). 0300-8177/81/0381-0147/\$3.20.

(a) 1981, Martinus Nijhoff/Dr. W. Junk Publishers, The Hague. Printed in the Netherlands. 
of GABA and other amino acids from multibarrel micropipettes. While GABA strongly inhibited firing of spinal cord neurons, they concluded that GABA was not the major inhibitory neurotransmitter in spinal cord. In a later study, Curtis and coworkers (8) demonstrated that GABA produced hyperpolarization and increased conductance and that the GABA-responses had a reversal potential similar to that of inhibitory postsynaptic potentials recorded in spinal cord. It is now well accepted that GABA is a major inhibitory neurotransmitter throughout the CNS (9-12) and modification of GABAergic inhibition has been determined to be involved in the actions of a number of drugs used clinically such as barbiturates (13-18) and benzodiazepines $(13,18-24)$ and in certain disease states such as epilepsy (25) and Huntington's Disease (26-28).

The purpose of the present article is to review the pharmacology of GABA-mediated inhibition in the spinal cord both in vivo and in primary dissociated cell culture. In addition, we will review the pharmacology of several drugs which have actions on GABAergic synaptic transmission with particular emphasis on convulsants, anticonvulsants and anesthetics. While it has been possible to gain much information from studies of spinal cord neurons in vivo, considerable technical advantage for investigation of GABA-mediated inhibition can be obtained by growing spinal cord neurons in primary dissociated cell culture. Therefore, we will review: 1) the technique of dissociated cell culture and the properties of spinal cord and dorsal root ganglion neurons in cell culture; 2) the metabolism, uptake, binding, and release of GABA and the action of drugs acting on these systems; 3 ) the physiology of GABA in both in vivo and in vitro preparations; and 4) the actions of convulsant, anticonvulsant and anesthetic drugs which antagonize or enhance GABA-responses and the releationship between their actions on GABA-responses and their physiological and pharmacological effects.

\section{Mammalian spinal cord neurons in primary dissociated cell culture}

Mammalian spinal cord (SC) and dorsal root ganglion (DRG) neurons can be grown and maintained in primary dissocîtated cell culture. Cultures

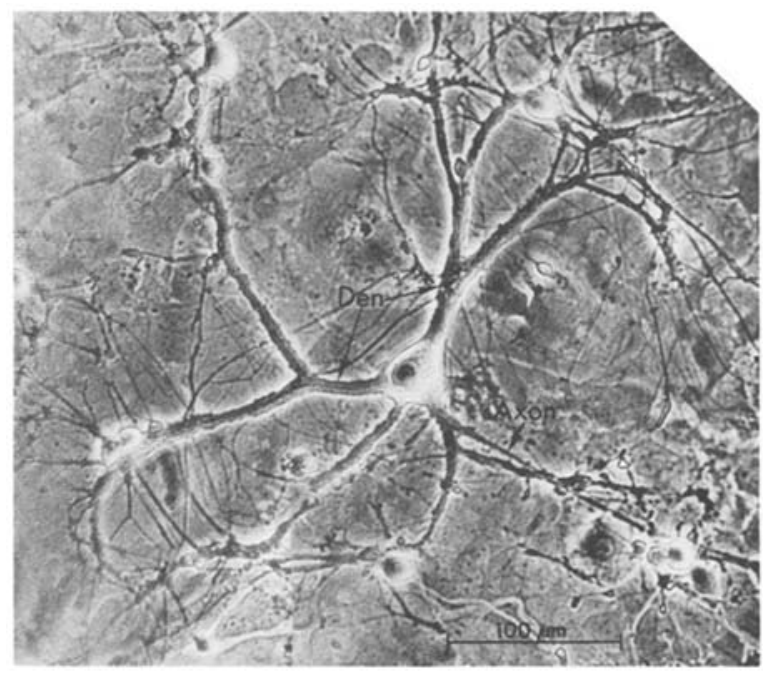

Fig. 1. Spinal cord neuron in primary dissociated cell culture. The large spinal cord neuron is multipolar with four large dendrites (Den) emerging from the soma and a single axon having its origin from a proximal segment of one of the dendrites. Magnification is $\times 225$. (From Ref. (202)).

are prepared from spinal cord and attached dorsal root ganglia obtained from fetal animals using the methods developed by Fischbach (29) and Nelson (30). SC-DRG neuronal cocultures derived from fetal mice contain both SC and DRG neurons which can be unambiguously identified using morphological and electrophysiological criteria (30).

Large SC neurons ( $>20 \mu \mathrm{M}$ diameter somata) are multipolar with several dendrites emerging from their somata (Fig. 1). Dendrites are covered with synaptic terminals over most of their membrane surface. A single axon usually emerges from the soma or from a proximal dendritic site and makes numerous synaptic contacts with other SC neurons (31). DRG neurons are round, contain sharply defined nuclei and nucleoli and are usually unipolar or bipolar. DRG neurons receive no synaptic input but DRG axons make synaptic contacts on SC neurons.

Electrophysiological properties of SC and DRG neurons in cell culture are similar to those of neurons in vivo (30). SC neurons display considerable spontaneous synaptic activity and depolarization evokes overshooting sodium-dependent action potentials. DRG neurons do not have spontaneous activity and intracellular stimulation evokes over- 


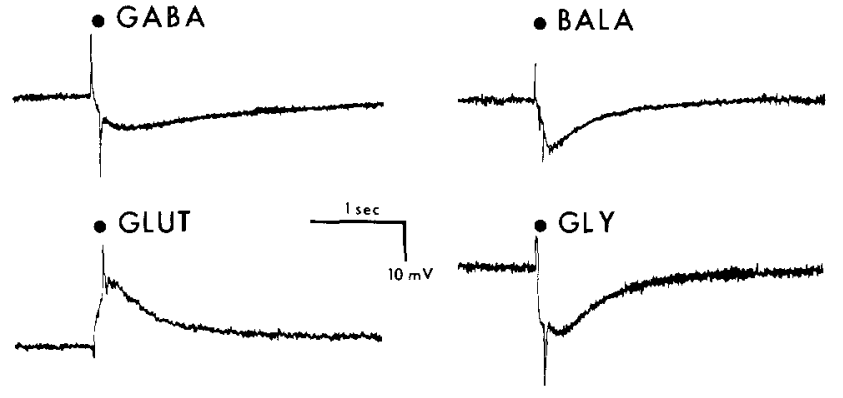

Fig. 2. Spinal cord neurons in cell culture respond to GABA (30 $\mathrm{nA}), \beta$-alanine (BALA) $(60 \mathrm{nA})$ and glycine (GLY) $(30 \mathrm{nA})$ with a membrane hyperpolarization and to glutamate (GLU) $(40 \mathrm{nA})$ with a depolarization. Amino acids were applied by iontophoresis for $100 \mathrm{msec}$. All responses were obtained from a single neuron and membrane potential varied from -40 to $-44 \mathrm{mV}$. (From Ref. (36)).

shooting action potentials dependent upon both sodium and calcium.

Since neurons grow in a monolayer in primary dissociated cell culture, it is possible to obtain intracellular recordings under visual control from individual neurons, to apply neurotransmitters or drugs to selected somatic or dendritic locations using iontophoretic or pressure ejection techniques or to superfuse the culture with neurotransmitters or drugs. Individual neurons can also be penetrated by two independent micropipettes to apply the voltage clamp technique.

Synaptic transmission between DRG and SC or between SC and SC neurons can be studied by simultaneously recording from neuron pairs (31-33). Excitatory and inhibitory postsynaptic potentials can be evoked from SC neurons while only excitatory postsynaptic potentials have been evoked by DRG stimulation.

The postsynaptic amino acid pharmacology of SC neurons has been well characterized (34-36). The majority of SC neurons $(>90 \%)$ respond to iontophoretically applied inhibitory neutral amino acids (GABA, $\beta$-alanine, glycine) and to the excitatory acidic amino acid glutamic acid (Fig. 2).

Thus SC and DRG neurons in primary dissociated cell culture have been demonstrated to have typical differentiated neuronal morphology, rich synaptic connectivity and extensive amino acid sensitivity and provide an excellent preparation for study of the physiology and pharmacology of SC and DRG neurons in vivo.

\section{GABA metabolism}

GABA has a unique regional distribution in the nervous system as does the enzyme responsible for its synthesis, L-glutamic acid decarboxylase (GAD) (37). Levels are highest in substantia nigra and lowest in brainstem and spinal cord. Within spinal cord, GABA levels are highest in the dorsal and dorsolateral part of dorsal horn (38). The synthesis and degradation of GABA is similar throughout the nervous system.

The immediate precursor for GABA is L-glutamic acid. The formation of GABA from glutamate was described in the first papers reporting the discovery of GABA in CNS tissues $(1,2,3)$. L-Glutamate is derived principally from glutamine and $\alpha$ ketoglutarate, the latter originating from the tricarboxylic acid cycle and glucose. However, alternative pathways have been described and various metabolic compartments of both glutamate and GABA exist (39). GAD (E.C.4.1.1.15) is the enzyme which catalyzes the formation of GABA from glutamate. GAD has a molecular weight of 85000 daltons and requires pyridoxal phosphate (40). The enzyme is cytoplasmic and is the ratelimiting enzyme in GABA synthesis. It is concentrated in the terminals of GABAergic neurons. The enzyme has been purified, antibodies raised against it and the immunocytochemical localization studied in CNS (41-43). In spinal cord, GAD-positive terminals are concentrated in Rexeds laminae I, II and III and axo-axonic, axodendritic and axosomatic terminals have been demonstrated. All three types of connections are also seen in ventral horn and deep layers of dorsal horn (41-43).

There are a variety of agents that interfere with GAD activity either directly or as antagonists of pyridoxal phosphate. Antagonists of pyridoxal phosphate are primarily carbonyl trapping agents such as isoniazid and thiosemicarbazide. These agents not only inhibit GAD but also GABAtransaminase (GABA-T) (this enzyme is responsible for GABA degradation and also requires pyridoxal phosphate). Depending on which enzyme is inhibited preferentially, GABA levels can be raised or lowered by these agents. Direct inhibitors of GAD, such as 3-mercaptoproprionic acid and allylglycine, are convulsants whose actions appear directly correlated with their abilities to reduce GABA levels (44-46). 
GABA is degraded by the enzyme 4aminobutyrate: 2-oxoglutarate aminotransferase (E.C.2.6.1.19) (GABA-T). The reaction is the transamination of $\alpha$-ketoglutarate with GABA to form glutamate and succinic semialdehyde. The enzyme (47) is localized to mitochondria and, like $\mathrm{GAD}$, requires pyridoxal phosphate (48). The molecular weight of GABA-T is 109000 daltons, the $\mathrm{K}_{\mathrm{m}}$ for GABA is $1.1 \mathrm{mM}$ and $0.25 \mathrm{mM}$ for $\alpha$-ketoglutarate (40). The enzyme makes one molecule of glutamate for every molecule of GABA destroyed, thus continually replenishing the precursor supply for GABA. The enzyme has been purified and antibodies raised against it $(41-43,49)$. Distribution studies have shown the enzyme associated with the mitochondria of synaptic terminals, glia and postsynaptic neuronal regions. Carbonyl trapping agents inhibit GABA-T by interferring with pyridoxal phosphate. One of these is aminooxyacetic acid (AOAA) which has been shown to act preferentially on GABA-T, raising GABA levels at low doses but causing convulsions at higher doses (secondary to inhibitory of GAD). Recently, several irreversible inhibitors of GABA-T have been described and promoted as possible anticonvulsants (50-53). The two agents studied most extensively have been $\gamma$-acetylenic GABA (4-amino-hex-5ynoic acid) and $\gamma$-vinyl GABA (4-amino-hex-5enoic acid). These agents cross the blood brain barrier and thus could be used clinically. Unfortunately, at high doses these drugs also effect GAD and perhaps several other enzymes as well $(50,51,53)$. A very potent GABA-T inhibitor, gabaculline ((-)-5-amino-1, 4-cyclohexadienyl carboxylic acid); has a $\mathrm{K}_{\mathrm{i}}$ of approximately $1 \mu \mathrm{M}$ for GABA-T and is only weakly inhibitory on GAD (54).

The last enzyme in GABA degradation is succinic semialdehyde dehydrogenase (E.C. 1.2.1.24) (SSADH). This enzyme is associated with mitochondria and is distributed similarly to GABA-T $(48,55)$. The reaction converts succinic semialdehyde to succinic acid which enters the tricarboxylic acid cycle (56). Valproic acid (sodium ndipropylacetic acid), which has been found useful as an anticonvulsant in humans, produced a dose dependent increase in GABA levels in animals. The agent was originally thought to be an anticonvulsant secondary to inhibition of GABA-T (57) but more recently it has been shown to be a more potent inhibitor of SSADH (58) and more importantly to directly augment GABA responses recorded electrophysiologically (59). We have found that valproic acid is a weak inhibitor of GAD, GABA-T and SSADH ( IC $_{50}$ 's greater than $15 \mathrm{mM}$ for all three enzymes) in mouse brain and spinal cord neurons in dissociated cell culture. The doses needed to cause $50 \%$ inhibition were much above that necessary for anticonvulsant effects (60).

\section{GABA uptake}

GABA is actively accumulated into nervous tissues by both high and low affinity transport systems $(61,62)$. The high affinity uptake is saturable, temperature-sensitive and sodium- and energy-dependent. High affinity uptake has been selectively evaluated by incubating small tissue slices or brain homogenates with low concentrations $\left(10^{-5}\right.$ to $\left.10^{-8} \mathrm{M}\right)$ of radioactively labeled GABA for short time periods (less than $10 \mathrm{~min}$ ) $(63,64)$. Under these conditions little GABA is metabolized. The high affinity uptake system has a $\mathrm{K}_{\mathrm{m}}$ of 5-40 $\mu \mathrm{M}$ depending on the preparation (64). In nervous tissue, it is felt that uptake occurs primarily into GABAergic nerve terminals. It has even been possible to show GABA uptake into specific populations of synaptosomes by sucrose gradient centrifugation (65). Nevertheless, there are several studies which indicate that high affinity uptake systems are also present on glial cells in certain tissues such as rat sensory ganglia and cultured rat glial tumor cells (66-69). There is also controversy over whether GABA uptake actually functions as a mechanism for GABA inactivation. There is evidence that the apparent uptake is really a net exchange. A variety of conflicting studies exist on GABA uptake and the functions of the various transport systems have yet to be resolved (68, 70-73).

Autoradiographic techniques have been the most reliable way of determining which tissue elements accumulate GABA. In brain, the percentage of nerve terminals labeled by ${ }^{3} \mathrm{H}-\mathrm{GABA}$ has a regional distribution consistent with the predicted distribution of GABAergic terminals $(74,75)$. In spinal cord homogenates, it has been demonstrated that approximately $25 \%$ of synaptic terminals were labeled when incubated with either ${ }^{3} \mathrm{H}-\mathrm{GABA}$ or 
${ }^{3} \mathrm{H}$-glycine alone (74). When incubated with both labeled amino acids together, approximately 50\% of the terminals were labeled, suggesting that the two amino acids were accumulated into separate populations of terminals. More recently, lesions of specific brain regions or pathways have been shown to selectively decrease GABA uptake in the projection areas of these pathways $(63,70,76)$. Thus, measurement of GABA uptake is a valuable technique in the mapping of GABAergic pathways.

GABA uptake has been studied in organ culture and dissociated cell culture of nervous tissue (77-79). In spinal cord cultures, a great number of neurons and almost all glial cells were labeled after incubation with ${ }^{3} \mathrm{H}-\mathrm{GABA}$. In cerebellar cultures, glia, interneurons and Purkinje cells accumulated GABA. In dorsal root ganglia cultures, neurons were labeled only if they had been stripped of glial elements, otherwise only satelite glial cells were labeled (77).

In dissociated cell cultures of embryonic chick spinal cord, GABA uptake has been studied chemically and by autoradiography (79). Both high and low affinity systems were observed with $K_{m}$ s of 4 and $100 \mu \mathrm{M}$ respectively. The high affinity system was temperature-sensitive, sàturable and sodiumdependent and inhibited more potently by $2,4-$ diaminobutyric acid than $\beta$-alanine. Autoradiography demonstrated uptake into about one half the multipolar neurons and an absence of uptake into glia and nonneuronal cell types.

Blockers of the GABA transport system have been studied rather extensively (80-82). 2,4Diaminobutyric acid (DABA) and nipecotic acid have been found to be more potent in inhibiting uptake into nerve terminals and neurons than $\beta$ alanine (83). Recently, 土-cis-3-aminocyclohexanecarboxylic acid has been found to be a more selective inhibitor of neuronal uptake than DABA or nipecotic acid (84). Of all the uptake blockers that have been studied, the most potent are Rnipecotic acid $\left(\mathrm{IC}_{50}=8 \mu \mathrm{M}\right)$, and cis-4-hydroxynipecotic acid $\left(\mathrm{IC}_{50}=12 \mu \mathrm{M}\right)(85)$. The active molecular conformations for inhibition of neuronal GABA uptake differ somewhat from the conformations for optimal inhibition of glial uptake $(86,87)$. Furthermore, structure activity studies indicate that the conformation of GABA that interacts with the transport system is quite different from that which interacts with GABA synaptic receptors.
Inhibitors of GABA uptake may enhance the neurophysiologic depressant effects of GABA $(88,89)$. However, they do not cross the blood brain barrier. Ethyl esters of nipecotic acid cross into brain and protect against pentylenetetrazole seizure but their pharmacologic effectiveness in humans is unknown (85).

\section{GABA release}

The release of GABA from superfused tissues, glial cells, brain and spinal cord slices and synaptosomes has been studied extensively in recent years (90-96). There have been, however, conflicting data as to whether the release is calcium-dependent and whether certain forms of stimulation. (i.e. electrical, potassium or veratradine) are better than others. Potassium evoked release of exogenously labelled GABA has been demonstrated to be calcium dependent in brain slices and synaptosomes $(92,93,95,97,99,101)$. Electrical or veratradine induced release of GABA was less consistently calcium-dependent $(97,99,102)$. In culture systems, potassium-evoked release of exogenously labeled ${ }^{3} \mathrm{H}$-GABA has been demonstrated and release was inhibited by reducing the extracellular $\mathrm{Ca}^{++} / \mathrm{Mg}^{++}$ratio (78). The pharmacology of the GABA release was not investigated in culture. In mouse neurons in dissociated cell culture, we found that exogenously labelled GABA was released by high-potassium and also was dependent on the $\mathrm{Ca}^{++} / \mathrm{Mg}^{++}$ratio. The release was. inhibited by GABA but not by DABA, $\beta$-alanine, muscimol, barbiturates or bicuculline. Glial preparations have been found to accumulate GABA (see previous section) and to release GABA after potassium stimulation $(96,103,104,105)$. However, glial release did not appear to be calcium dependent $(96,105)$.

Release of GABA and other neurotransmitters may be regulated by presynaptic GABA receptors (106-109). The calcium-dependent potassiumevoked release of GABA from substantia nigra was inhibited by both GABA and muscimol; however, bicuculline also inhibited the release and additional pharmacology was not reported (108). Recently, GABA has been shown to facilitate the release of ${ }^{3} \mathrm{H}$-dopamine from caudate nucleus $(106,107)$ but the effect was not antagonized by bicuculline nor 
picrotoxin, and others have found an inhibition of ${ }^{3} \mathrm{H}$-dopamine release from striatal slices by GABA (109). The discrepancies in the results as to whether GABA facilitates or inhibits release may be secondary to technical differences in experimental methodology. It does appear clear, however, that the pharmacology of these presynaptic receptors may be quite different from that of postsynaptic receptors (106-109).

\section{GABA binding}

The electrophysiological effects of GABA on neuronal membrane properties have been studied extensively, and it has also been possible to study GABA receptors biochemically by binding studies (110-114). The correlation of biochemical and neurophysiological data hopefully will allow a better understanding of the GABA receptor complex. Most binding studies to date have been performed in different preparations than the physiological studies making comparisons difficult. Mammalian neurons in primary dissociated cell culture provide a single system in which biochemical data and physiological data can be directly compared (115-118).

A variety of ligands have been used to probe the properties of the GABA receptor complex. The two commonly used agonists are ${ }^{3} \mathrm{H}-\mathrm{GABA}$ and ${ }^{3} \mathrm{H}-$ muscimol. ${ }^{3} \mathrm{H}-\mathrm{GABA}$ binds saturably to synaptic membranes and binding has a pharmacology and a subcellular and regional distribution consistent with that of the synaptic GABA receptor. Two binding sites can be discerned in nervous tissue, a low and a high affinity site with $\mathrm{K}_{\mathrm{D}^{\mathrm{s}}}$ of about $20 \mathrm{nM}$ to about $200 \mathrm{nM}$, respectively (119).

In initial studies of GABA binding, two conditions for binding were demonstrated $(110,120)$. If nervous tissue membranes were freshly prepared and incubated with ${ }^{3} \mathrm{H}-\mathrm{GABA}$ in the presence of sodium, then binding was not bicuculline sensitive and had a pharmacology similar to the uptake site (so-called sodium-dependent binding). If membranes were frozen and assayed for binding in the absence of sodium, binding was bicuculline sensitive and had a pharmacology consistent with the synaptic receptor (so-called sodium-independent binding). Initial studies of these sodiumindependent sites suggested one population of

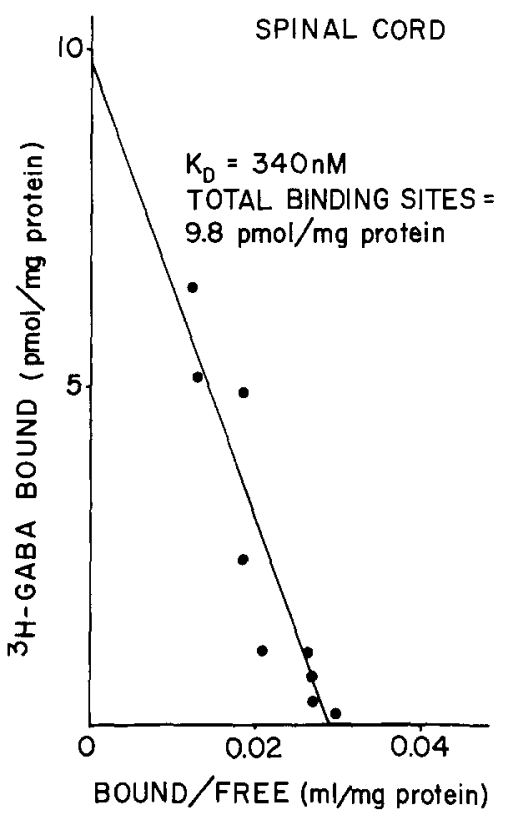

Fig. 3. Scatchard analysis of specific ${ }^{3} \mathrm{H}-\mathrm{GABA}$ binding to adult rat spinal cord membranes. Membranes from whole spinal cord homogenized in $50 \mathrm{mM}$ Tris-citrate buffer, $\mathrm{pH} 7,1$ at $4{ }^{\circ} \mathrm{C}$ were incubated at $37^{\circ} \mathrm{C}$ for $30 \mathrm{~min}$ with $0.05 \%$ Triton $\mathrm{X}-100(\mathrm{v} / \mathrm{v})$ and then centrifuged at $48000 \times \mathrm{g}$ for $10 \mathrm{~min}$. The membranes were washed 3 times with fresh ice cold buffer and finally resuspended in buffer. Aliquots of the suspension (0.2-0.8 $\mathrm{mg}$ protein) were incubated in triplicate with increasing concentrations of ${ }^{3} \mathrm{H}$ $\mathrm{GABA}(1-500 \mathrm{nM})$ at $4{ }^{\circ} \mathrm{C}$ for $20 \mathrm{~min}$. The assay was terminated by filtration over Whatman $\mathrm{GF} / \mathrm{B}$ glass fiber filters. Specific binding $(\bullet)$ was obtained by subtracting from the total ${ }^{3} \mathrm{H}-$ GABA bound, that bound in the presence of $0.1 \mathrm{mM}$ GABA (run in triplicate). The experiment has been repeated four times.

binding sites. Subsequent studies, however, demonstrated that two sites became apparent if the tissue was pretreated with the detergent Triton X100 or if the membranes were repeatedly frozen and thawed and then washed extensively (119). Furthermore, this procedure increased the affinity of GABA for its receptor by at least one order of magnitude. It occurred to several investigators that this phenomenon might represent the removal of an endogenous GABA receptor modulator from the neuronal membranes (GABA-modulin) (121-123). Some of the 'modulator' may be GABA itself but a relatively small protein or peptide has also been implicated. The distribution of the high affinity sites varied quite dramatically throughout the CNS. The number of high affinity sites was highest in the cerebellum and lowest in the spinal cord $(124,125)$. In our laboratory we have studied ${ }^{3} \mathrm{H}-\mathrm{GABA}$ 


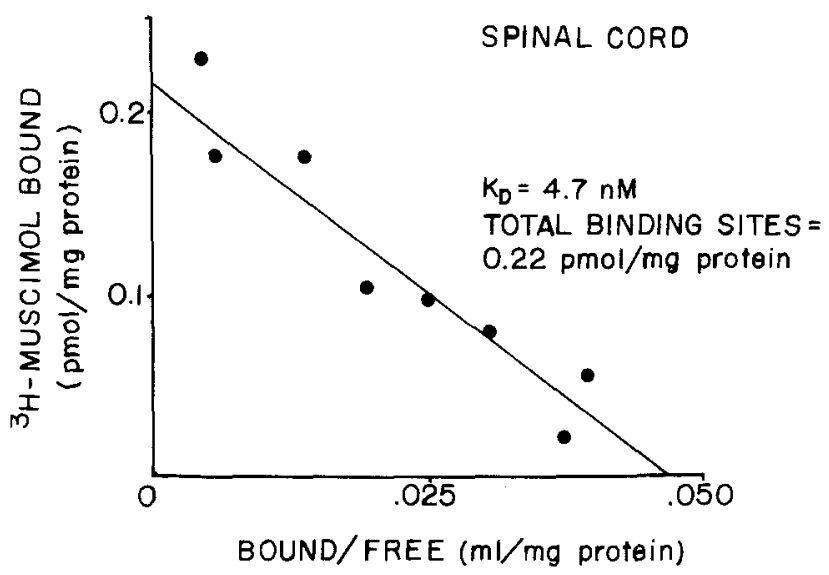

Fig. 4. Scatchard analysis of specific ${ }^{3} \mathrm{H}$-muscimol binding to adult rat spinal cord membranes. The assay was identical to that described for ${ }^{3} \mathrm{H}$-GABA in Fig. 3, however, ${ }^{3} \mathrm{H}$-muscimol was the labeled ligand. The experiment has been replicated four times.

binding in spinal cord and only low affinity sites $\left(\mathrm{K}_{\mathrm{D}}=340 \mathrm{nM} ; \mathrm{B}_{\max }=9.8 \mathrm{pmol} / \mathrm{mg}\right.$ prot $)$ could be demonstrated (Fig. 3) whereas in brain the identical technique indicated two sites (low affinity $\mathrm{K}_{\mathrm{D}}=210$ $\mathrm{nM}, \mathrm{B}_{\max }=10.1 \mathrm{pmol} / \mathrm{mg}$ prot, and high affinity $\mathrm{K}_{\mathrm{D}}=20 \mathrm{nM}, \mathrm{B}_{\max }=1.5 \mathrm{pmol} / \mathrm{mg}$ prot).

${ }^{3} \mathrm{H}-\mathrm{Muscimol}$ also binds to central nervous GABA receptors but only to the high affinity site in tritonized tissue (126-128). We have found that, in

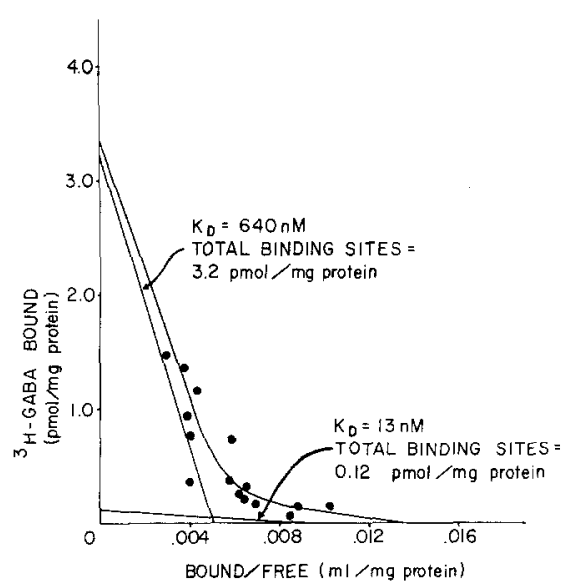

Fig. 5. Scatchard analysis of specific ${ }^{3} \mathrm{H}-\mathrm{GABA}$ binding to membranes from mouse spinal cord neurons in dissociated cell culture prepared as described in Fig. 3 except that $0.025 \%$ Triton $\mathrm{X}-100$ was used and two washes were carried out and the membranes centrifuged for $20 \mathrm{~min}$ at $48000 \times \mathrm{g}$. The results are the combined data from two experiments and the experiment has been replicated four times. brain, the $K_{D}$ for ${ }^{3} \mathrm{H}$-muscimol binding was $6 \mathrm{nM}$ and the $B_{\max }$ was $1.7 \mathrm{pmol} / \mathrm{mg}$ prot which was similar to the $B_{\max }$ of the high affinity GABA receptor binding site. When we studied ${ }^{3} \mathrm{H}-$ muscimol in tritonized spinal cord membranes, only one binding site was found with a $K_{D}=6 n M$ and $\mathrm{B}_{\max }=0.24 \mathrm{pmol} / \mathrm{mg}$ protein (Fig. 4). The ratio therefore of high to low affinity sites in spinal cord was 1:40. Such a ratio precluded accurate quantitation of the high affinity site in spinal cord using ${ }^{3} \mathrm{H}-\mathrm{GABA}$. Even in routine assays at very low concentrations of ${ }^{3} \mathrm{H}-\mathrm{GABA}$, the relative contribution of the low affinity site was substantial.

The high affinity GABA and muscimol binding sites are considered to be associated with the postsynaptic complex (129). Lesions of various nuclei receiving GABAergic input lead to a loss of high affinity receptor sites (129). Also, the high affinity receptor sites are the ones that increased during the development of supersensitivity. In spinal cord in cell culture, we found two binding sites for GABA (Fig. 5) and only a high affinity site for muscimol. The $\mathrm{K}_{\mathrm{D}^{\mathrm{s}}}$ for the two GABA binding sites were similar to those found in rat brain and spinal cord although the ratio of high to low affinity sites was higher than that of rat spinal cord. The location of the low affinity sites have not been studied and their significance is unknown.

The pharmacology of the high affinity site revealed that various receptor agonists (as judged by neurophysiological criteria) competed for ${ }^{3} \mathrm{H}-$

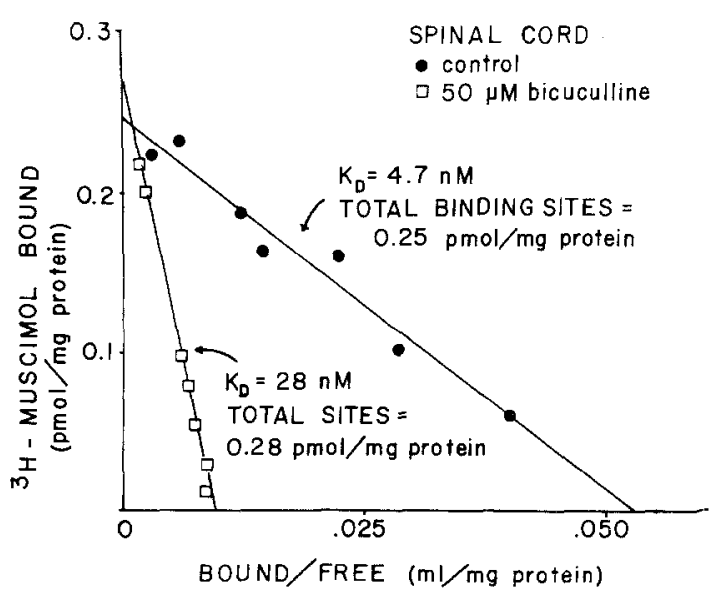

Fig. 6. Scatchard analyses of ${ }^{3} \mathrm{H}$-muscimol binding in adult rat spinal cord membranes alone $(\bullet)$ and in the presence of $50 \mu \mathrm{M}$ bicuculline ( $\square$ ). The assay is identical to that in Fig. 3. The experiment has been replicated four times. 
GABA binding (130-133). Muscimol, 3-aminopropanesulphonic acid and dihydromuscimol are three potent receptor agonists. Structure activity studies have shown a specific optimal conformation of GABA for interaction with its receptor, different from the conformations which interact with the uptake sites, GAD and GABA-T $(134,135)$.

Very few GABA antagonists inhibit GABA binding. (+)-Bicuculline is the most potent antagonist with an $\mathrm{IC}_{50}=5 \mu \mathrm{M}$ (134). Other convulsant agents have been investigated and the only ones approaching $(+)$-bicuculline in potency were $(+)$ adlumidine, n-propylbicyclophosphate and nbutylbicyclophosphate (136). Bicuculline appeared to be a competitive inhibitor or GABA both by physiological criteria and by biochemical studies (Fig. 6) (136, 137). As indicated earlier, the affinity of GABA receptors could be enhanced dramatically by pretreating membrane fractions with Triton $\mathrm{X}-100$ or by repeated freezing and thawing of the membranes with subsequent extensive washing (119). Such treatment of membranes, however, did not influence the $\mathrm{K}_{\mathrm{I}}$ for bicuculline which is difficult to explain if it was indeed interacting strictly competitively with GABA at the receptor site. Furthermore, various anions enhanced the effectiveness of bicuculline in inhibiting GABA binding without changing the affinity of GABA itself (116). Although analysis of the effect of bicuculline on GABA dose response curves indicated competitive inhibition, such studies must be considered carefully. It is possible for a substance to exhibit linear competitive inhibition and nevertheless bind to a site separate from (but closely linked to) the site for the natural substrate (138).

$A$ variety of other agents that antagonized or enhanced GABA responses in physiological experiments had no effect on GABA binding (110, $112,113)$. These included picrotoxinin, pentylenetetrazole, penicillin, barbiturates and the benzodiazepines. It is therefore unlikely that these drugs interact directly with the GABA recognition site but rather with a closely related site such as the chloride channel. Several of these agents have been labeled and binding to synaptic membranes studied (139-141). Several studies using ${ }^{3} \mathrm{H}$-bicuculline methiodide have been published but this agent was not very stable, was difficult to prepare and few detailed studies have been possible. ${ }^{3} \mathrm{H}$-Dihydropicrotoxinin binding has been reported. Binding was not displaced by GABA and was weakly displaced by bicuculline (142). However, binding was displaced by picrotoxin analogues, barbiturates and the so-called cage convulsants in potencies similar to their clinical potencies. Finally, benzodiazepine binding studies have demonstrated a class of benzodiazepine receptors intimately related to GABA receptors (143-146). GABA enhanced binding to benzodiazepine receptors as did a variety of GABA analogs. Anions also enhanced benzodiazepine binding suggesting that there may be an association of the receptor with the chloride channel together in the same fractions $(145,147)$. Diazepam has also been found to interact with GABA modulin and thereby increase the affinity of GABA binding. The GABA receptor and the benzodiazepine receptor can be solubilized together $(148,149)$.

The GABA receptor complex is certainly far from being completely understood. However, multiple probes are now available to do quite detailed studies on various receptor components and their interactions.

\section{GABA-mediated inhibition in the mammalian spinal cord}

In the mammalian spinal cord GABAergic interneurons are presumed to have at least two different sites of action. Release of GABA onto primary afferent terminals would produce presynaptic inhibition while release onto somatic and dendritic locations would produce postsynaptic inhibition.

Stimulation of primary afferents to the spinal cord produced a prolonged depolarization of primary afferent fibers (primary afferent depolarization (PAD)) $(150,151)$. PAD was associated with reduction of monosynaptic EPSPs recorded in anterior horn cells following orthodromic volleys in muscle and cutaneous afferents and was thought to be due to decreased release of transmitter from the primary afferent terminals. Eccles and coworkers (152) suggested that the reduction in transmitter release was due to release of transmitter from axoaxonic synapses located on the synaptic terminals of primary afferent fibers and also that the neurotransmitter involved might be GABA (153). Application of GABA to isolated spinal cord produced depolarization of dorsal root fibers (154-157) and GABA depolarized dorsal root 
ganglion cells (158-161). These actions of GABA were blocked by the GABA antagonists picrotoxin and bicuculline (157-161). Thus while GABA did alter membrane potential of primary afferent terminals it produced depolarization rather than the usual hyperpolarization associated with inhibition. Nonetheless, using immunohistochemical techniques Roberts and his colleagues (41-43) demonstrated that GAD-positive (and thus presumably GABAergic) axoaxonic contacts were made on primary afferent terminals. Based on ion substitution experiments, blockade of chloride channels and intracellular recording from dorsal root ganglion neurons it has been demonstrated that GABA increased chloride conductance and that depolarization was produced because the equilibrium potential for chloride ions was depolarized relative to resting membrane potential $(159,161,162)$. Thus, there is physiological, pharmacological and anatomical evidence to support the notion that presynaptic inhibition in the dorsal horn is GABAmediated. PAD, however, may have two different underlying mechanisms. The early picrotoxinsensitive depolarization is probably due to release of GABA onto presynaptic terminals while the late phase is most likely a consequence of elevated interstitial potassium produced by the large afferent volley $(163,164)$.

GABA-mediated postsynaptic inhibition is also probably present in the spinal cord. As discussed above, GABA levels are highest in the dorsal and dorsolateral portions of the dorsal horn (38). However, Roberts and his colleagues (41-43) have demonstrated GAD-positive terminals on both dorsal and ventral horn neurons. In the dorsal horn, GAD-positive terminals were identified on the somata of substantia gelatinosa neurons as well as the dendrites of Rexeds layer IV neurons. The lateral portion of the intermediate spinal gray matter and motor nuclei had a light concentration of GAD-positive material. Furthermore, most of the spinal cord neurons studied had at least some GAD-positive terminals on their somata and often on their dendrites. Thus there is immunocytochemical evidence for widespread distribution of GABAergic synaptic terminals. Consistent with this, spinal cord neurons were hyperpolarized by GABA $(7-10,165)$ and this hyperpolarization was due to an increase in membrane chloride conductance (166). Despite these findings, much post- synaptic inhibition in the spinal cord was strychnine-sensitive and bicuculline-insensitive implying that it was glycinergic (167). This includes short latency, strychnine-sensitive inhibition of motoneurons produced by single volleys in afferents from cutaneous and muscle nerves, inhibition of spinal interneurons and inhibition of firing of Renshaw cells produced by volleys in hindlimb cutaneous fibers (167-171). Nevertheless, while glycine may be the major neurotransmitter mediating postsynaptic inhibition in the spinal cord, there is substantial evidence that GABAmediated postsynaptic inhibition is also present in the spinal cord.

\section{GABA-mediated postsynaptic inhibition in spinal cord neurons in cell culture}

Application of GABA onto SC neurons in cell culture using iontophoretic or pressure techniques produced both membrane potential and conductance changes (34-36). During intracellular recordings with micropipettes containing. $4 \mathrm{M}$ potassium acetate, GABA application produced membrane hyperpolarization and an increase in membrane conductance. GABA-response amplitude was a function of membrane potential, and the responses could be reversed by membrane hyperpolarization. The average reversal potential for GABA-responses was $-61.1 \mathrm{mV}$ with an average resting membrane potential of $-54.6 \mathrm{mV}$ (35). The hyperpolarized reversal potential of GABAresponses associated with increased conductance suggested that either chloride and/or potassium conductance was involved in the response. The role of chloride conductance was examined by altering intra- and extracellular chloride concentrations and determining reversal potentials (35). Injection of chloride ions into $\mathrm{SC}$ neurons from intracellular recording micropipettes containing $3 \mathrm{M} \mathrm{KCl}$ reduced the reversal potential of GABA-responses to $-20.3 \mathrm{mV}$ without altering resting membrane potential. Reduction of chloride ions from the bathing medium attenuated GABA-responses but addition of extracellular chloride from a large bore pipette restored the response. Thus, GABAresponses are chloride dependent. Similar experiments which increased extracellular potassium concentration did not alter the GABA-response 
reversal potential initially, but after sustained potassium induced depolarization, the reversal potential was decreased. This result suggested that potassium was not involved in GABA-responses and that the late changes in GABA-response reversal potential were due to redistribution of chloride ions induced by sustained depolarization. Thus, GABAmediated inhibitory responses of SC neurons in cell culture are due to an increase in chloride conductance.

Sensitivity to GABA was not uniform over the surface of SC neurons $(34,35)$ with focal areas of increased sensitivity being distributed over the cell surface. Whether or not these 'hot spots' correspond to localized regions of subsynaptic GABAreceptors is uncertain.

We have used the voltage clamp technique to study membrane currents induced by GABA (168). SC neurons were penetrated by two independent intracellular micropipettes. One micropipette recorded transmembrane potential and the other applied current. The voltage clamp apparatus held membrane potential by applying current through the current micropipette, and it was the applied current that was recorded. Under clamp conditions, the reversal potential for GABA-responses was $8-10 \mathrm{mV}$ more negative than resting membrane potential. We were able to obtain dose-response data during voltage clamp and demonstrate that when the log of the membrane current was plotted as a function of the log of the GABA iontophoretic current, a limiting slope averaged 1.5. This suggested that GABA interacts with the GABA-receptor in a cooperative manner with at least two GABA molecules being required to activate the chloride conductance mechanism.

Since the voltage clamp technique can be applied to SC neurons, conductance fluctuation (or 'noise') analysis can also be applied to investigation of GABA-mediated inhibition (173). Individual SC neurons were impaled with two independent micropipettes and GABA was applied by iontophoresis. Experiments had to be performed at $26^{\circ} \mathrm{C}$ to reduce desensitization. The GABA induced increase in noise was analyzed using fluctuation analysis assuming that the noise derived was from statistical variation in the number of open ion channels activated by GABA with a mean level of open channels. Using this analysis, the average conductance of a single channel activated by GABA was $18 \pm 8.2 \mathrm{pS}$. Using spectral analysis of fluctuations during the plateau phase of the current responses, the average duration of the GABA channel open time was $20 \pm 6.6 \mathrm{msec}$.

Thus, GABA inhibits SC neurons in primary dissociated cell culture by increasing chloride conductance and hyperpolarizing membrane potential. At least two molecules of GABA appear necessary to activate chloride channels. Activation of GABAreceptors briefly opens individual chloride channels with small unitary channel conductance.

\section{Antagonists of GABA-mediated inhibition}

The compounds bicuculline(BICUC), picrotoxin (PICRO), pentylenetetrazol (PTZ) and penicillin (PCN) produce convulsions when applied to the mammalian CNS. The action of these agents on SC neurons in cell culture was investigated by applying GABA, other amino acids and convulsants by iontophoresis to focal areas of somata of $\mathrm{SC}$ neurons $(174,175)$. None of the convulsants altered membrane potential or input resistance but all four convulsants rapidly and reversibly antagonized GABA-responses (Fig. 7). The antagonism of GABA-mediated inhibition was selective for GABA since responses to the amino acids $\beta$-alanine, glycine and glutamate were unaffected by convulsant concentrations that antagonized GABAresponses. Using spinal cord neurons in cell culture, we have compared the antagonism of GABAresponses by $\mathrm{BICUC}$ with the displacement of ${ }^{3} \mathrm{H}$ GABA by BICUC. BICUC displaced high affinity ${ }^{3} \mathrm{H}-\mathrm{GABA}$ binding with an $\mathrm{ED}_{50}$ of $15 \mu \mathrm{M}$ and an $\mathrm{ED}_{20}$ of $4 \mu \mathrm{M}$ (Young, Frere and Macdonald, unpublished work). Antagonism of GABAresponses was produced with an $\mathrm{ED}_{50}$ of $1 \mu \mathrm{M}$ and an $\mathrm{ED}_{100}$ of $10 \mu \mathrm{M}$. (Macdonald, Nowak and Young, unpublished work). Thus the physiologically relevant displacement of binding occurred over 1 to $10 \mu \mathrm{M}$ BICUC concentrations and high affinity binding was correlated with antagonism of postsynaptic GABA-responses.

While all of these convulsants (PICRO, BICUC, PCN, PTZ) antagonized GABA-responses, their sites of action are uncertain. Since none of the convulsants antagonized glycine responses, which are also chloride-mediated, it is unlikely that they combine nonspecifically with all chloride channels. 


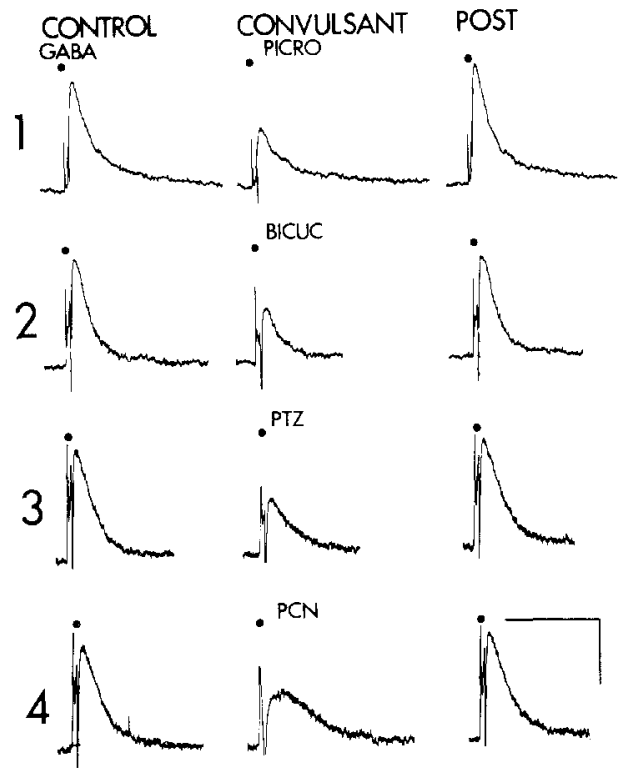

Fig. 7. GABA-responses were antagonized reversibly by the convulsants picrotoxin (PICRO), bicuculline (BICUC), pentylenetetrazol (PTZ) and penicillin (PCN). GABA was applied by iontophoresis (50 msec. pulses) and intracellular recordings were made by glass micropipettes containing $3 \mathrm{M}$ $\mathrm{KCl}$. Membrane potential was hyperpolarized to -80 to $-90 \mathrm{mV}$ and chloride ions were injected intracellularly. Thus GABA reversal potentials were depolarized to about $-20 \mathrm{mV}$ and the GABA-responses were depolarizing rather than hyperpolarizing. Calibration bars are $10 \mathrm{mV} \times 1 \mathrm{~s}$. (From Ref. (175)).

However, to antagonize GABA-responses each convulsant could combine: 1) with the active site of the GABA-receptor to competitively antagonize GABA-responses, 2) with the GABA-coupled chloride channel to non-competitively antagonize GABA-responses or 3) with a modulator site which either alters the affinity of the receptor for GABA, modifies the coupling between the receptor and chloride channel or changes chloride channel function (decrease unitary channel open time or conductance). While adequate studies of the effect of GABA-antagonists on GABA dose-response curves on spinal cord neurons have not been published, some information is available from other preparations. Much of the quantitative electrophysiological data has been obtained using lobster, crayfish and crab muscle since in these preparations intracellular penetrations can be maintained for the extended time period required for acquisition of dose-response data.
With intracellular recording techniques applied to invertebrate muscle fibers (176-178) and cat dorsal root ganglion neurons (161), BICUC antagonized GABA-induced increases in conductance noncompetitively. Using extracellular recording from spinal cord interneurons in lamprey (179) and cuneate neurons $(180,181)$ BICUC antagonism was competitive. Using similar techniques, PICRO antagonized GABA-responses on invertebrate muscle fibers in a competitive (173), noncompetitive $(182,183)$ and mixed (178) fashion. PICRO antagonized GABA-responses competitively on invertebrate crayfish stretch receptor neurons (184) but noncompetitively on vertebrate dorsal root ganglion neurons (161), spinal cord interneurons (179) and cuneate neurons $(180,181)$. PCN antagonized GABA-responses primarily noncompetitively in both invertebrate muscle fibers (185) and vertebrate cuneate neurons (186). Dose-response data for PTZ action on GABA-responses has not been published. In summary, BICUC, PICRO and PCN antagonize GABA-mediated inhibition in invertebrate muscle fibers and vertebrate dorsal root ganglion neurons noncompetitively. In studies of vertebrate central neurons PICRO and $\mathrm{PCN}$ are also noncompetitive antagonists but BICUC appears to be a competitive antagonist. From a technical point of view, the data from muscle fibers and dorsal root ganglion neurons was obtained using in tracellular recording while that from central neurons was either extracellular unit recordings or extracellular d.c. potentials. The intracellular data certainly more accurately reflects the actions of agonists and antagonists than does extracellular recording and therefore the data demonstrating noncompetitive antagonism is more likely to accurately reflect the interaction between convulsants and GABA-responses. Thus, it is likely that in invertebrate muscle the convulsants act on a site other than the GABA-recognition site, either the GABA-coupled chloride channel or the coupling mechanism between the receptor and the channel.

It is likely that these compounds produce convulsions by antagonizing GABA-mediated postsynaptic inhibition. Using the hippocampal slice preparation, Yamamoto (187) demonstrated that paroxysmal depolarizing shifts (PDS) can be recorded from $\mathrm{CA}_{3}$ pyramidal neurons following addition of the convulsant strychnine. PDS are the intracellular correlate of interictal 'spikes' recorded. 
in the scalp electroencephalogram of patients with epilepsy (188-190). The PDS are calciumdependent depolarizations of dendritic origin (191) which are activated by orthodromic stimulation but do not invade the neuronal soma due to orthodromic disynaptic (presumably GABAergic) somatic inhibition (192). Antagonism of the inhibitory postsynaptic potentials by $\mathrm{PCN}$, however, permits somatic invasion by the calcium-dependent depolarization and this results in PDS (193). PCN also produces spinal myoclonus in animals and man, presumbably also by blockade of GABAmediated postsynaptic inhibition. Thus, it is likely that reduction of GABA-mediated inhibition may be involved in the pathogenesis of some forms of human epilepsy and spinal myoclonus.

\section{Augmentors of GABA-mediated inhibition}

Barbiturates, benzodiazepines and valproic acid are all used clinically as anticonvulsants. In addition, barbiturates and benzodiazepines are employed therapeutically to reduce anxiety and facilitate sleep. Short acting barbiturates are also useful as anesthetics. The mechanisms of action of these compounds are uncertain but numerous preand postsynaptic actions have been described and many of these actions involve GABAergic transmission. Presynaptic actions of barbiturates include: 1) augmentation of GABA-mediated presynapticinhibition $(13,16) ; 2)$ depression of evoked transmitter release from dorsal root afferents (194); 3) augmentation of evoked transmitter release at the neuromuscular junction $(195,196)$; and 4) direct depolarization of dorsal root afferents which is blocked by the GABA antagonist picrotoxin (16). Postsynaptic effects of barbiturates include: 1) augmentation of GABA-mediated inhibition (15, $17,18) ; 2$ ) antagonism of glutamate-mediated excitation $(15,18)$; 3$)$ reduction of excitatory synaptic transmission; and 4) direct hyperpolarization of spinal cord motoneurons which is blocked by picrotoxin (15).

Benzodiazepines have multipleactions including: 1) augmentation of GABA-mediated presynaptic inhibition (19-21); 2) enhancement $(197,198)$ and antagonism $(199,200)$ of GABA-mediated postsynaptic inhibition; and 3) direct depolarization of sympathetic preganglionic nerve terminals (22).
Valproic acid (VPA) has been shown to have a primarily presynaptic action to increase central nervous system GABA levels (57), by antagonizing the major GABA degradative enzymes including GABA-T (57) and, more importantly, SSADH (58). It was suggested that this enhancement of presynaptic GABA would increase GABA-mediated inhibition.

We have used mouse spinal cord neurons in primary dissociated cell culture to investigate the action of these compounds on postsynaptic GABAresponses, other amino acid responses and on resting membrane properties

The anticonvulsant (phenobarbital $(\mathrm{PhB})$ and mephobarbital (MB)) (Fig. 8) and sedativeanesthetic (pentobarbital (PB) and secobarbital (SB)) barbiturates $(18,201)$, the benzodiazepines (diazepam (DZ) and chlordiazepoxide (CDZ)) (18, 202) and valproic acid (57) all augmented GABAresponses without altering glycine responses. The mechanistic basis for this modulation of GABAresponses is uncertain but it is clear that, since these compounds augmented rather than antagonized GABA-responses, they did not compete with GABA for the GABA-binding site on the GABA receptor. We have proposed that they bind to a modulator site on the GABA-receptor chloride-channel complex to alter GABA-responses (201-203). Since barbiturates, benzodiazepines and valproic acid do not alter the affinity of saturable ${ }^{3} \mathrm{H}-\mathrm{GABA}$ binding to spinal cord or brain membranes, it is likely that these compounds do not bind to the GABA recognition site of GABA-receptors but instead bind to a separate site located on the GABA-receptor chloride-channel complex which alters either: 1) the

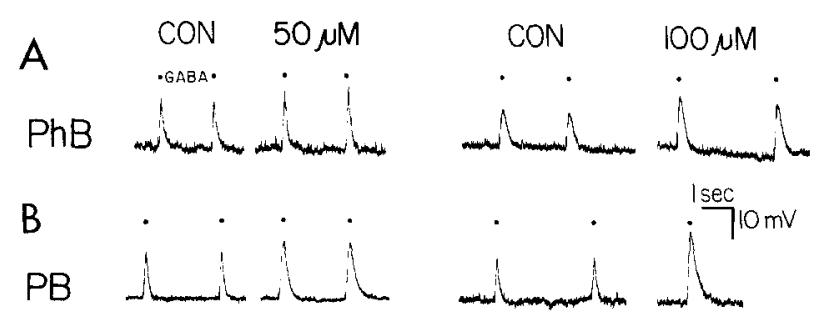

Fig. 8. GABA-responses were augmented by phenobarbital and pentobarbital. GABA was applied by iontophoresis $(\mathrm{PhB}$ : 4,5 nA; PB: 3,2.5 nA) for $100 \mathrm{msec}$, recordings were made with micropipettes containing $3 \mathrm{M} \mathrm{KCl}$ and membrane potential was hyperpolarized to -60 to $-90 \mathrm{mV}$ to achieve large depolarizing GABA-responses. (Macdonald \& Schulz, unpublished work.) 
coupling between GABA-binding and chloride channels or 2) the GABA-coupled chloride channel properties to increase unitary channel conductance or open time.

Barbiturates, but not benzodiazepines or valproic acid, also antagonized excitatory glutamateresponses $(18,203)$. For $\mathrm{PB}$ and $\mathrm{PhB}$, the two actions occurred at the same drug concentration with $\mathrm{PB}$ being somewhat more potent than $\mathrm{PhB}$. In addition, both $\mathrm{PB}$ and $\mathrm{PhB}$ directly increased neuronal chloride conductance independent of GABA (201, 203). This direct action of the barbiturates was antagonized by the GABA-antagonists PCN and PICRO, suggesting that the barbiturates were 'GABA-mimetic.' However, as discussed above, barbiturates have not been demonstrated to displace ${ }^{3} \mathrm{H}-\mathrm{GABA}$ from GABA-binding sites and thus the available evidence suggests that the barbiturates do not bind directly to the GABA-binding site to increase chloride conductance but rather bind to an adjacent site similar to that which PICRO binds. Thus barbiturates could bind: 1) to the GABA-receptor chloride channel complex and activate the GABA-coupled chloride channel independent of the GABA-binding site, 2) to an independent 'barbiturate receptor' which is also coupled to chloride channels or 3) to the GABAcoupled chloride channel with direct activation of the chloride channels.

Despite having multiple actions, it is likely that specific actions of these compounds are responsible for their clinical actions. Augmentation of GABAmediated postsynaptic inhibition is probably responsible for the anticonvulsant actions of the barbituates and benzodiazepines and possibly for valproic acid. The anesthetic actions of barbiturates are probably due to: 1) direct activation of chloride conductance, 2) augmentation of GABAmediated inhibition and possibly antagonism of glutamate-mediated excitation and 3 ) reduction of presynaptic calcium-entry leading to a generalized diminution of synaptic transmission. Thus, the GABA-receptor chloride channel complex is a major site of action for the clinical actions of these compounds.

\section{References}

1. Awapara, J., Landua, A. J., Fuerst, R. \& Seale, B., 1950. J. Biol. Chem. 187: 35-39.
2. Roberts, E. \& Frankel, S., 1950. J. Biol. Chem. 187: 55-66.

3. Udenfriend, S., 1950. J. Biol. Chem. 187: 65-69.

4. Hayashi, T., 1954. J. Med. 3: 183-192.

5. Florey, E., 1954. Arch. Intern. Physiol. 62: 33-53.

6. Bazemore, A. W., Elliott, K. A. C. \& Florey, E., I957. J. Neurochem. 1: 334-339.

7. Curtis, D. R., Phillis, J. W. \& Watkins, J. C., 1959. J. Physiol. (Lond.) 146: 185-203.

8. Curtis, D. R., Hosli, L., Johnston, G. A. R. \& Johnston, I. H., 1968. Exper. Brain Res. 5: 235-258.

9. Curtis, D. R. \& Johnston, G. A. R., 1974. Ergeb. Physiol. 9: $98-188$.

10. Krnjevic, K., 1974. Physiol. Rev. 54: 418-450.

11. Roberts, E., 1974. Biochem. Pharmacol. 23: 2637-2649.

12. Krnjevic, K., 1976. In: GABA in nervous system function (Roberts, E., Chase, T. N. \& Tower, D. B., eds.), pp. 269-281, Raven Press, New York.

13. Schmidt, R. F., 1971. Ergeb. Physiol. Biol. Chem. Exp. Pharmacol. 63: 20-101.

14. Nicoll, R. A., 1972. J. Physiol. (Lond.) 223: 803-814.

15. Nicoll, R. A., 1975. Brain Res. 96: 119-123.

16. Nicoll, R. A., 1975. Proc. Nat. Acad. Sci. (USA) 72: 1460-1463.

17. Ransom, B. R. \& Barker, J. L., 1976. Brain Res. 114: $530-535$.

18. Macdonald, R. L. \& Barker, J. L., 1979. Brain Res, 167: 323-336.

19. Schlosser, W., 1971. Arch. Int. Pharmacodyn. 194: 93-102.

20. Polc, P., Mohler, H.\& Haefely, W., 1974. Arch. Pharmacol. 284: 319-337.

21. Haefely, W., Kulesar, A., Mohler, H., Pieri, L., Polc, P. \& Shaffner, R., 1975. Advanc. Biochem. Psychopharmacol. 10: $131-152$.

22. Suria, A. \& Costa, E., 1975. Brain Res. 87: 102-106.

23. Mohler, H. \& Okada, T., 1977. Science 198: 849-851.

24. Squires, R. F. \& Braestrup, C., 1977. Nature (Lond.) 266: 732-734.

25. Meldrum, B. S., 1975. Int. Rev. Neurobiol. 17: 1-36.

26. Hornykiewicz, O., 1972. In: Handbook of neurochemistry, Vol. 7 (Lajtha, A., ed.), pp. 465-501, Plenum Press, New York.

27. Hornykiewicz, O., Lloyd, K. G. \& Davidson, L., 1976. In: The GABA system, function of the basal ganglia, and Parkinson's disease (Roberts, E., Chase, T. N. \& Tower, D. B., eds.), pp. 479-485, Raven Press, New York.

28. Chase, T. N., 1976. The basal ganglia association for research in nervous and mental disease, pp. $337-349$, Raven Press, New York.

29. Fischbach, G. D., 1972. Develop. Biol. 28: 407-429.

30. Ransom, B. R., Neale, E., Henkart, M., Bullock, P. N. \& Nelson, P. G., 1977. J. Neurophysiol. 40: 1132-1150.

31. Neale, E. A., Macdonald, R. L. \& Nelson, P. G., 1978. Brain Res. 152: 265-282.

32. Ransom, B. R., Christian, C. N., Bullock, P. N. \& Nelson, P. G., 1977. J. Neurophys. 40: 1151-1162.

33. Nelson, P. G., Neale, E. A. \& Macdonald, R. L., 1980. Excitable cells in Tissue culture (Nelson, P. G. \& Lieberman, M., eds.), Plenum Press, New York.

34. Ransom, B. R., Bullock, P. N. \& Nelson, P. G., 1977. J. Neurophysiol. 40: 1163-1177. 
35. Barker, J. L. \& Ransom, B. R., 1978. J. Physiol. (Lond.) 280: 331-354.

36. Macdonald, R. L. \& Barker, J. L., 1980. Excitable cells in tissue culture (Nelson, P. G. \& Lieberman, M., eds.), Plenum Press.

37. Fahn, S., 1976. GABA in nervous system function (Roberts, E., Chase, T. N. \& Tower, D. B., eds.), pp. 169-186, Raven Press, New York.

38. Otsuka, M. \& Konishi, S., 1976. GABA in nervous system function (Roberts, E., Chase, T. N. \& Tower, D. B., eds.), pp. 197-202, Raven Press, New York.

39. Baxter, C. F., 1976. GABA in nervous system function (Roberts, E., Chase, T. N.\& Tower, D. B., eds.), pp. 61-87, Raven Press, New York.

40. Wu, J-Y., 1976. GABA in nervous system function (Roberts, E., Chase, T. N. \& Tower, D. B., eds.), pp. 7-55, Raven Press, New York.

41. MeLaughlin, B. J., Barber, R., Saito, K., Roberts, E. \& Wu, J-Y., 1975. J. Comp. Neurol. 164: 305-322.

42. Wood, J. G., MeLaughlin, B. J. \& Vaughn, J. E., 1976. GABA in nervous system function (Roberts, E., Chase, T. N. \& Tower, D. B., eds.), pp. 149-168, Raven Press, New York.

43. Barber, R. P., Vaughn, J. E., Saito, K., McLaughlin, B. J. \& Roberts, E., 1978. Brain Res. 141: 35-55.

44. Horton, R. W. \& Meldrum, B. S., 1973. Brit. J. Pharmacol. 49: $52-63$.

45. Karlsson, A., Fonnum, F., Malthe-Sorenssen, D. \& Storm-Mathisen, J., 1974. Biochem. Pharmacol. 23: 3053-3061.

46. Orlowski, M., Reingold, D. F. \& Stanley, M. E., 1977. J. Neurochem. 28: 349-353.

47. Salvador, R. A.\& Albers, R. W., 1959. J. Biol. Chem. 234: 922-925.

48. Sheridan, J. J., Sims, K. L. \& Pitts, F. N., Jr., 1967. J. Neurochem. 14: 571-578.

49. Barber, R. \& Saito, K., 1976. GABA in nervous system function (Roberts, E., Chase, T. N. \& Tower, D. B., eds.), pp. 113-132, Raven Press, New York.

50. Jung, M. J., Lippert, B., Metcalf, B. W., Schechter, P. J., Bohlen, P. \& Sjoerdsma, A., 1977. J. Neurochem. 28: 717-723.

51. Jung, M. J., Lippert, B., Metcalf, B. W., Bohlen, P. \& Schechter, P. J., 1977. J. Neurochem. 29: 797-802.

52. Jung, M. J., Lippert, B., Casara, P., Bohlen, P. \& Schechter, P. J., 1978. GABA neurotransmitters: phar macochemical, biochemical and pharmacochemical, aspects (Krogsgaard-Larsen, P., Scheel-Kruger, J. \& Kofod, H., eds.), pp. 228-235, Academic Press, New York.

53. Perry, T. L., Kish, S. J. \& Hansen, S., 1979. J. Neurochem. 32: 1641-1645.

54. Rando, R. R., 1978. GABA-neurotransmitters: pharmacochemical, biochemical and pharmacological aspects (Krogsgaard-Larsen, P. \& Scheel-Kruger, J., eds.), pp. 228-235, Academic Press, New York.

55. Miller, A. L. \& Pitts, F. N., Jr., 1967. J. Neurochem. 14: 579-584.

56. Pitts, F. N., Jr \& Quick, C., 1965. J. Neurochem. 12: 893-900.
57. Godin, Y., Heiner, L., Mark, J. \& Mandel, P., 1969. J. Neurochem. 16: 869-873.

58. Van Der Laan, J. W., DeBoer, T. H. \& Bruinvels, J., 1979. J. Neurochem. 32: 1769-1780.

59. Macdonald, R. L. \& Bergey, G. K., 1979. Brain Res, 170: 558-562.

60. Frere, R. C., Young, A. B. \& Macdonald, R. L., 1980. Neurosci. Abstr. 6: 56.

61. Weinstein, H., Varon, S., Muhleman, D. R. \& Roberts, E., 1965. Biochem. Pharmacol. 14: 273-388.

62. Iversen, L. L. \& Neal, M. J., 1968. J. Neurochem. 15: 1141-1149.

63. Kuhar, M. J., 1973. Life Sci. 13: 1623-1634.

64. Martin, D. L., 1976. GABA in nervous system function (Roberts, E., Chase, T. N. \& Tower, D. B., eds.), pp. 347-386, Raven Press, New York.

65. Iversen, L. L. \& Snyder, S. H., 1968. Nature (Lond.) 220: 796-798.

66. Henn, F. A. \& Hamberger, A., 1971. Proc. Nat. Acad. Sci. (USA) 68: 2686-2690.

67. Schon, F. \& Kelly, J. S., 1974. Brain Res. 66: 289-300.

68. Schrier, B. K. \& Thompson, E. J., 1974. J. Biol. Chem. 249: 1769-1780.

69. Hosli, L. \& Hosli, E., 1979. GABA - Biochemistry and CNS functions (Mandel, P. \& DeFuedis, F. V., eds.), pp. 205-218, Plenum Publishing Corp., New York.

70. Storm-Mathisen, J., Fonnum, F. \& Malthe-Sorenssen, D., 1976. GABA in nervous system function (Roberts, E., Chase, T. N. \& Tower, D. B., eds.), pp. 387-394, Raven Press, New York.

71. Ryan, L. D. \& Roskoski, R., Jr., 1977. J. Pharmacol. Exp. Ther. 200: 285-291.

72. Levi, G., Banay-Schwartz, M. \& Raiteri, M., 1978. Amino acids as chemical transmitters (Fonnum, F., ed.), pp. 327-350, Plenum Publishing Corporation, New York.

73. Cutler, R. W. P. \& Young, J., 1979. Brain Res. 165: 261-270.

74. Iversen, L. L. \& Bloom, F. E., 1972. Brain Res. 41: 131-143.

75. Ljungdahl, A.\& Hokfelt, T., 1973. Brain Res. 62: 587-595.

76. Penney, J. B. \& Young, A. B., 1980. Brain Res.

77. Hosli, E. \& Hosli, L., 1978. Maturation of neurotransmission (Vernadakis, A., Giacobini, E., Filogamo, G. \& Karger, S., eds.), pp. 108-115, Basel.

78. Farb, D. H., Berg, D. K. \& Fischbach, G. D., 1979. J. Cell. Biol. 80: 651-661.

79. Hosli, E. \& Hosli, L., 1980. Exp Brain Res. 38: 241-243.

80. Krogsgaard-Larsen, P. \& Johnston, G. A. R., 1975. J. Neurochem. 25: 797-802.

81. Johnston, G. A. R., 1976. GABA in nervous system function (Roberts, E., Chase, T. N. \& Tower, D. B., eds.), pp. 395-411, Raven Press, New York.

82. Wood, J. D., Tsui, D. \& Phillis, J. W., 1979. Can. J. Physiol. Pharmacol. 57: 581-585.

83. Kelly, J. S. \& Dick, F., 1975. Cold Spring Harbor Symp. Quant. Biol. 9: 93-106.

84. Bowery, N. G., Jones, G. P. \& Neal, M. J., 1976. Nature (Lond.) 264: 281-284. 
85. Brehm, L., Krogsgaard-Larsen, P. \& Jacobsen, P., 1978. GABA neurotransmitters: pharmacochemical, biochemical and pharmacological aspects (Krogsgaard-Larsen, P., Scheel-Kruger, J. \& Kofod, H., eds.), pp. 247-262, Academic Press, New York.

86. Iversen, L. L. \& Kelly, J. S., 1975. Biochem. Pharmacol. 24: 933-938.

87. Schousboe, A., 1978. GABA neurotransmitters: pharmacochemical, biochemical and pharmacological aspects (Krogsgaard-Larsen, P., Scheel-Kruger, J. \& Kofod, H., eds.), pp. 263-280, Academic Press, New York.

88. Krogsgaard-Larsen, P., Johnston, G. A. R., Curtis, D. R., Game, C. J. A. \& McCulloch, R. M., 1975. J. Neurochem. 25: 803-809.

89. Lodge, D., Johnston, G. A. R., Curtis, D. R. \& Brand, J., 1977. Brain Res. 136: 513-522.

90. Hammerstad, J. P., Murray, J. E. \& Cutler, R. W. P., 1971. Brain Res. 35: 357-367.

91. Mitchell, J. F. \& Roberts, P. J., 1972. Br. J. Pharmacol. 45: 175-176P.

92. Levy, W. B., Redburn, D. A. \& Cotman, C. W., 1973. Science 181: 676-678

93. Mulder, A. H. \& Snyder, S. H., 1974. Brain Res. 76: 297-308.

94. Gauchy, C. M., Iversen, L. L. \& Jessell, T. M., 1977. Brain Res. 138: 374-379.

95. Vargas, O., DeLorenzo, M., Saldate, M. \& Orrego, F., 1977. J. Neurochem. 28: 165-170.

96. Sellstrom, A. \& Hamberger, A., 1977. Brain Res. 119: 189-198.

97. Hammerstad, J. P., Cawthon, M. L. \& Lytle, C. R., 1979. J. Neurochem. 32: 195-202.

98. Leach, M. J., 1979. J. Pharm. Pharmacol. 31: 533-535.

99. Szerb, J. C., 1979. J. Neurochem. 32: 1565-1573.

100. Collins, G. G. S., 1973. Br. J. Pharmacol. 47: 641 P.

101. Cotman, C. W., Haycock, J. W. \& White, W. F., 1976. J. Physiol. (Lond.) 254: 475-505.

102. Srinivasan, V., Neal, M. J. \& Mitchell, J. F., 1969. J. Neurochem. 16: 1235-1244.

103. Bowery, N. G. \& Brown, D. A., 1972. Nature, New Biol. 238: 89-91.

104. Bowery, N. G. \& Neal, M. J., 1978. J. Physiol. (Lond.) 275: $58 \mathrm{P}$.

105. Minchin, M. C. W., 1975. J. Neurochem. 24: 571-577.

106. Starr, M. S., 1979. Eur. J. Pharmacol. 53: 215-226.

107. Stoof, J. C., DenBreejen, E. J. S. \& Mulder, A. H., 1979. Eur. J. Pharmacol. 57: 35-42.

108. Kamal, L., Arbilla, S. \& Langer, S. Z., 1980. Presynaptic receptors(Langer, S.Z.etal., eds.), pp. 193-197, Pergamon Press, New York.

109. Bowery, N. G., Hill, D. R., Hudson, A. L., Doble, A., Middlemiss, D. N., Shaw, J. \& Turnbull, M., 1980. Nature (Lond.) 283: 92-94.

110. Zukin, S. R., Young, A. B. \& Snyder, S. H., 1974. Proc. Natl. Acad. Sci. (USA) 71: 4802-4807.

111. Enna, S. J. \& Snyder, S. H., 1975. Brain Res. 100: 81-97.

112. Olsen, R. W., Greenlee, D., VanNess, P. \& Ticku, M. K., 1978. Amino acids as chemical transmitters (Fonnum, F., ed.), Plenum Press, New York.
113. Olsen, R. W., Ticku, M. K., Greenlee, D. \& VanNess, P., 1978. GABA neurotransmitters: pharmacochemical, biochemical and pharmacological aspects (KrogsgaardLarsen, P., Scheel-Kruger, J. \& Kofod, H., eds.), pp. 165-178, Academic Press, New York.

114. Olsen, R. W., Ticku, M. K., VanNess, P. C. \& Greenlee, D., 1978. Brain Res. 139: 277-294.

115. Young, A. B. \& Macdonald, R. L., 1979. Neurosci. Abstr. 5: 602 .

116. Macdonald, R. L., Young, A. B. \& Nowak, L. M., 1979. Neurosci. Abstr. 5: 593.

117. DeFeudis, F. V., Ossola, L., Schmitt, G., Wolff, P. \& Mandel, P., 1980. J. Neurochem. 34: 216-218.

118. Ticku, M. K., Huang, A. \& Barker, J. L., 1980. Brain Res. 182: 201-206.

119. Enna, S. J. \& Snyder, S. H., 1977. Mol. Pharmacol. 13: $442-453$

120. Young, A. B., Enna, S. J., Zukin, S. R. \& Snyder, S. H., 1976. GABA in nervous system function (Roberts, E., Chase, T. N. \& Tower, D. B., eds.), pp. 305-317, Raven Press, New York.

121. Greenlee, D. V., VanNess, P. C. \& Olsen, R. W., 1978. Life Sci. 22: 1653-1662.

122. Guidotti, A., Toffano, G. \& Costa, E., 1978. Nature (Lond.) 275: 553-555,

123. Toffano, G., Guidotti, A. \& Costa, E., 1978. Proc. Nat. Acad. Sci. (USA) 75: 4024-4028.

124. Enna, S. J., Ferkany, J. W. \& Krogsgaard-Larsen, F., 1978. GABA neurotransmitters: pharmacochemical, biochemical and pharmacological aspects (KrogsgaardLarsen, P., Scheel-Kruger, J. \& Kofod, H., eds.), pp. 191-200, Academic Press, New York.

125. Placheta, P. \& Karobath, M., 1979. Brain Res. 178: $580-583$

126. Beaumont, K., Chilton, W. S., Yamamura, H. I. \& Enna, S. J., 1978. Brain Res. 148: 153-162.

127. Snodgrass, S. R., 1978. Nature (Lond.) 273: 392-394.

128. Williams, M. \& Risley, E. A., 1979. J. Neurochem. 32: 713-718.

129. Guidotti, A., Gale, K., Suria, A.\& Toffano, G., 1979. Brain Res. 172: 566-571.

130. Enna, S. J. \& Maggi, A., 1979. Life Sci. 24: 1727-1738.

131. Galli, A., Zilletti, L., Scotton, M., Adembri, G. \& Giotti, A., 1979. J. Neurochem. 32: 1123-1125.

132. Krogsgaard-Larsen, P., Honore, J. \& Thyssen, K., 1978. GABA neurotransmitters: pharmacochemical, biochemical and pharmacological aspects (Krogsgaard-Larsen, P., Scheel-Kruger, J. \& Kofod, H., eds.), pp. 201-216, Academic Press, New York.

133. Krogsgaard-Larsen, P., Hjeds, H., Curtis, D. R., Lodge, D. \& Johnston, G. A. R., 1979. J. Neurochem. 32: 1717-1724.

134. Krogsgaard-Larsen, P., Johnston, G. A. R., Lodge, D. \& Curtis, D. R., 1977. Nature (Lond.) 268: 53-55.

135. Krogsgaard-Larsen, P. \& Johnston, G. A. R., 1978. J. Neurochem. 30: 1377-1382.

136. Enna, S. J., Collins, J. F. \& Snyder, S. H., 1977. Brain Res. 124: $185-190$.

137. Olsen, R. W., Ban, M. \& Miller, T., 1976. Brain Res. 102: 283-299.

138. Cleland, W. W., 1963. Biochem. Biophys. Acta 67: 188-196. 
139. Collins, J. F. \& Cryer, G., 1978. Amino acids as chemical transmitters (Fonnum, F., ed.), pp. 499-506, Plenum Press, New York.

140. Mohler, H. \& Okada, T., 1977. Nature (Lond.) 267: 65-67.

141. Mohler, H. \& Okada, T., 1978. Amino acids as chemical transmitters (Fonnum, F., ed.), pp. 493-498, Plenum Press, New York.

142. Ticku, M. K., Ban, M. \& Olsen, R. W., 1978. Mol. Pharmacol. 14: 391-402.

143. Braestrup, C. \& Squires, R. F., 1978. Eur. J. Pharmacol, 48: 263-270.

144. Tallman, J. F., Thomas, J. W. \& Gallager, D. W., 1978. Nature (Lond.) 274: 383-385.

145. Martin, I. L. \& Candy, J. M., 1978. Neuropharmacology 17:.993-998.

146. Tallman, J. F. \& Gallager, D. W., 1979. Pharmacol. Biochem. Behav. 10: 809-813.

147. Costa, T., Robard, D. \& Pert, C. B., 1979. Nature (Lond.) 277: 315-317.

148. Gavish, M., Chang, R. S. L. \& Snyder, S. H., 1979. Life Sci. 25: 783-790.

149. Gavish, M. \& Snyder, S. H., 1980. Life Sci. 26: 579-582.

150. Eccles, J. C., 1964. The Physiology of Synapses, SpringerVerlag, Berlin.

151. Levy, R. A., 1977. Prog. Neurobiol. 9: 211-267.

152. Eccles, J. C., Kostyuk, P. G. \& Schmidt, R. F., 1962. J. Physiol. (Lond.) 161: 237-257.

153. Eccles, J. C., Schmidt, R. F. \& Willis, W. D., 1963. J. Physiol. (Lond.) 168: 500-530.

154. Schmidt, R. F., 1963. Pflugers Arch. Ges. Physiol. 277: 325-346.

155. Tebecis, A. K. \& Phillis, J. W., 1967. Comp. Biochem. Physiol. 23: 553-563.

156. Davidoff, R. A., 1972. Science 175: 331-333.

157. Barker, J. L. \& Nicoll, R. A., 1972. Science 176: 1043-1045.

158. Feltz, P. \& Rasminsky, M., 1974. Neuropharmacol. 13: $553-563$.

159. Nishi, S., Minota, S. \& Karczmar, A. G., 1974. Neuropharmacol, 13: 215-219.

160. Deschenes, M., Feltz, P. \& Lamour, Y., 1976. Brain Res. 118: 486-492.

161. Gallagher, J. P., Higashi, H. \& Nishi, S., 1978. J. Physiol. (Lond.) 275: 263-282.

162. Nicoll, R. A., 1978. J. Physiol. (Lond.) 283: 121-132.

163. Sykova, E. \& Vyklicky, L., 1978. Neurosciences 3: 1061-1067.

164. Davidoff, R. A., Hackman, J. C. \& Osorio, I., 1980. Neurosciences 5: 117-126.

165. Krnjevic, K., Puil, E. \& Werman, R., 1977. Can. J. Physiol. Pharmacol. 55: 658-669.

166. Krnjevic, K.; 1976. GABA in nervous system function (Roberts, E., Chase, T. N. \& Tower, D. B., eds.), pp. 269-281, Raven Press, New York.

167. Curtis, D. R., Duggan, A. W., Felix, D. \& Johnston, G. A. R., 1971. Brain Res. 32: 69-96.

168. Bruggencate, G. ten \& Engberg, I., 1968. Brain Res. 11: 446-450.

169. Curtis, D. R., Hosli, L. \& Johnston, G. A. R., 1968. Exp. Brain Res. 6: $1-18$.

170. Curtis, D. R., Hosli, L., Johnston, G. A. R. \& Johnston, I. H., 1968. Exp. Brain Res. 5: 235-258.
171. Werman, R., Davidoff, R. A. \& Aprison, M. H., 1968. J. Neurophysiol. 31: 81-95.

172. Barker, J. L., Macdonald, R. L. \& Smith, T. G., 1977. J. Gen. Physiol. 70: 1a.

173. McBurney, R. N. \& Barker, J. L., 1978. Nature (Lond.) 274: 596-597.

174. Macdonald, R. L. \& Barker, J. L., 1977. Nature (Lond.) $267,720-721$

175. Macdonald, R. L. \& Barker, J. L., 1978. Neurology 28: 325-330.

176. Takeuchi, A. \& Onodera, K., 1972. Nature New Biol. 236: 55-56.

177. Shank, R. P., Pong, S. F., Freeman, A. R. \& Graham, L. T., 1974. Brain Res. 72: 71-78.

178. Constanti, A., 1978. Neuropharmacol. 17: 159-167.

179. Homma, S. \& Rovainen, C. M., 1978. J. Physiol. (Lond.) 279: $231-252$

180. Simmonds, M. A., 1978. Br. J. Pharmacol. 63: 495-502.

181. Simmonds, M. A., 1980. Neuropharmacol. 19: 39-45.

182. Takeuchi, A. \& Takeuchi, N., 1969. J. Physiol. (Lond.) 205: 377-391.

183. Earl, J. \& Large, W. A., 1974. J. Physiol. (Lond.) 236: 113-127.

184. Hori, N., Ikeda, K. \& Roberts, E., 1978. Brain Res. 14l: 364-370.

185. Hochner, B., Spira, M. E. \& Werman, R., 1976. Brain Res. 107: 85-103.

186. Pickles, H. G. \& Simmonds, M. A., 1980. Neuropharmacology 19: 35-38.

187. Yamamoto, C., 1972. Exp. Neurol. 35: 154-164.

188. Matsumoto, H., 1964. Electroencephalogr. Clin. Neurophysiol. 17: 294-307.

189. Prince, D. A., 1968. Exper. Neurol. 21: 467-485.

190. Dichter, M. \& Spencer, W. A., 1969. J. Neurophysiol. 32: 663-687.

191. Wong, R. K. S. \& Prince, D. A., 1978. Brain Res. 159: 385-390.

192. Wong, R. K. S., Prince, D. A. \& Basbaum, A. I., 1979. Proc. Natl. Acad. Sci. (USA) 76: 986-990.

193. Wong, R. K. S. \& Prince, D. A., 1970. Science 204: 1228-1231.

194. Weakly, J. N., 1969. J. Physiol. (Lond.) 204: 63-77.

195. Thomson, T. D. \& Turkanis, S. A., 1973. Br. J. Pharmacol. 48: 48-58.

196. Proctor, W. R. \& Weakly, J. N., 1976. J. Physiol. (Lond.) 258: 257-268.

197. Choi, D. W., Farb, D. H.\& Fischbach, G. D., 1977. Nature (Lond.) 269: 342-344.

198. Raabe, W. \& Gumnit, R. J., 1977. Epilepsia 18: 117-120.

199. Gahwiler, B. H., 1976. Brain Res. 107: 176-179.

200. Steiner, F. A. \& Felix, D., 1976. Nature (Lond.) 260: 346-347.

201. Macdonald, R. L. \& Barker, J. L., 1978. Science 200: 775-777.

202. Macdonald, R. L. \& Barker, J. L., 1978. Nature (Lond.) 271: 563-564.

203. Macdonald, R. L. \& Barker, J. L., 1979. Neurology 29: 432-447.

Received October 1, 1980. 